\author{
ACTA MYCOLOGICA \\ Vol. 47 (1): 109-119 \\ 2012
}

\title{
New records of Lobaria amplissima (Lobariaceae, Ascomycota) in Poland
}

\author{
ANNA ZALEWSKA ${ }^{1}$ and ADAM BOHDAN ${ }^{2}$ \\ ${ }^{1}$ Department of Botany and Nature Protection, Warmia and Mazury University in Olsztyn \\ Plac Łódzki 1, PL-10-727 Olsztyn, annazalw@uwm.edu.pl \\ ${ }^{2}$ Department of Botany, Institute of Biology, University of Białystok \\ Świerkowa 20B, PL-15-950 Białystok, adam.bohdan@wp.pl
}

Zalewska A., Bohdan A.: New records of Lobaria amplissima (Lobariaceae, Ascomycota) in Poland. Acta Mycol. 47 (1): 109-119, 2012.

The current knowledge on the occurrence of Lobaria amplissima, a very rare old-growth forest lichen in Poland, is discussed. Both previous and new localities are presented. The Białowieża Forest, from which L. amplissima is reported, is a refuge site of L. amplissima in the lowland forests of Central Europe. The most important data on the ecology and the general distribution of the species are given. Diagnostic characters related to the morphology, anatomy and chemistry of L. amplissima differentiating it from similar species are described.

Key words: lichenized fungi, ancient forest species, new records, Białowieża Forest

\section{INTRODUCTION}

Until recently, the genus Lobaria (Schreber) Hoffm. was represented in Poland by three species: L. linita (Ach.) Rabenh., L. pulmonaria (L.) Hoffm. and L. virens (With.) J.R. Laundon (Fałtynowicz 2003). Lobarina scrobiculata (Scop.) Cromb. was earlier also included as Lobaria scrobiculata (Scop.) DC. These species are legally protected (acc. to the Regulation of the Minister of Environment of 2004) and redlisted in Poland (Cieśliński et al. 2006). The terricolous or exceptionally saxicolous Lobaria linita (RE) is known only from historical records in the Sudety Mts and the Tatry Mts (Fałtynowicz 2003). Localities of the more frequent corticolous L. pulmonaria (EN) are confined to old forests, mostly in the north-eastern part of the Polish lowlands and in the Bieszczady Mts (Ryś 2005). This taxon is considered as indicator (IND) of old-growth forests in the Polish lowlands (Czyżewska, Cieśliński 2003). Lobarina scrobiculata (Scop.) Cromb. also has a similar morphology, ecology, and legal and relict status (CR - acc. to Cieśliński et al. 2006, IND - acc. to Czyżewska and 
Cieśliński 2003; as Lobaria scrobiculata on both lists). Its more recent localities are in the Białowieża Forest and the Bieszczady Mts (Cieśliński 2003; Fałtynowicz 2003).

Lobaria virens was erroneously reported from Poland. It was noted only at one locality in a well-preserved forest community (Cieśliński, Tobolewski 1988). This species was included into the Polish red-list in CR category (Cieśliński et al. 2006), and into the group of IND-lichens (Czyżewska, Cieśliński 2003).

The current list of Polish Lobaria species still consists of three taxa but L. virens was replaced by L. amplissima (Scop.) Forssell after a revision of the herbarium material deposited in BSG by M. Kukwa (Kukwa et al. 2008). The specimen collected in the Białowieża Forest by S. Cieśliński and Z. Tobolewski and published as Lobaria laetevirens (Lightf.) Zahlbr. = L. virens (With.) J.R. Laundon (Cieśliński, Tobolewski 1988; Cieśliński 2003) in fact belongs to L. amplissima. The new determination was based on the morphology and ascospore features. Further localities of Lobaria amplissima were recently discovered by A. Bohdan during field investigations on rare macrolichens in the Białowieża Forest.

This rare species has distinct, characteristic morphological and chemical features that help to distinguish it from other similar taxa. Despite its special ecological demands it is relatively poorly known in Poland (Nowak, Tobolewski 1975). The aim of the study was to present the species and to indicate the most important diagnostic characters. Habitat requirements of L. amplissima identified to date suggest that few further localities of the species are likely to occur in the least human-affected forest communities in Poland, especially in the north-eastern part of the country and probably in the Bieszczady Mts. The available scarce data on the occurrence of Lobaria amplissima in Poland are given in this study, including new records.

Several detailed morphological features described here (e.g., concerning rhizines) based on new specimens and older specimens stored in KRAM were not published before.

\section{MATERIAL AND METHODS}

The material was collected in 2010 and 2011. Specimens were identified with standard morphological and anatomical methods as well as using spot colour reaction tests and TLC to differentiate secondary metabolites (Smith et al. 2009; Orange et al. 2001). The square number of the modified ATPOL grid (Cieśliński, Fałtynowicz 1993 ) is given for the localities. The nomenclature of lichens follows Fałtynowicz (2003) and Diederich et al. (2009). The material was deposited in the herbarium of the Society „Workshop for All Beings”, Podlaskie Branch in Białystok, and in the herbarium of the Institute of Biology, University of Białystok. 


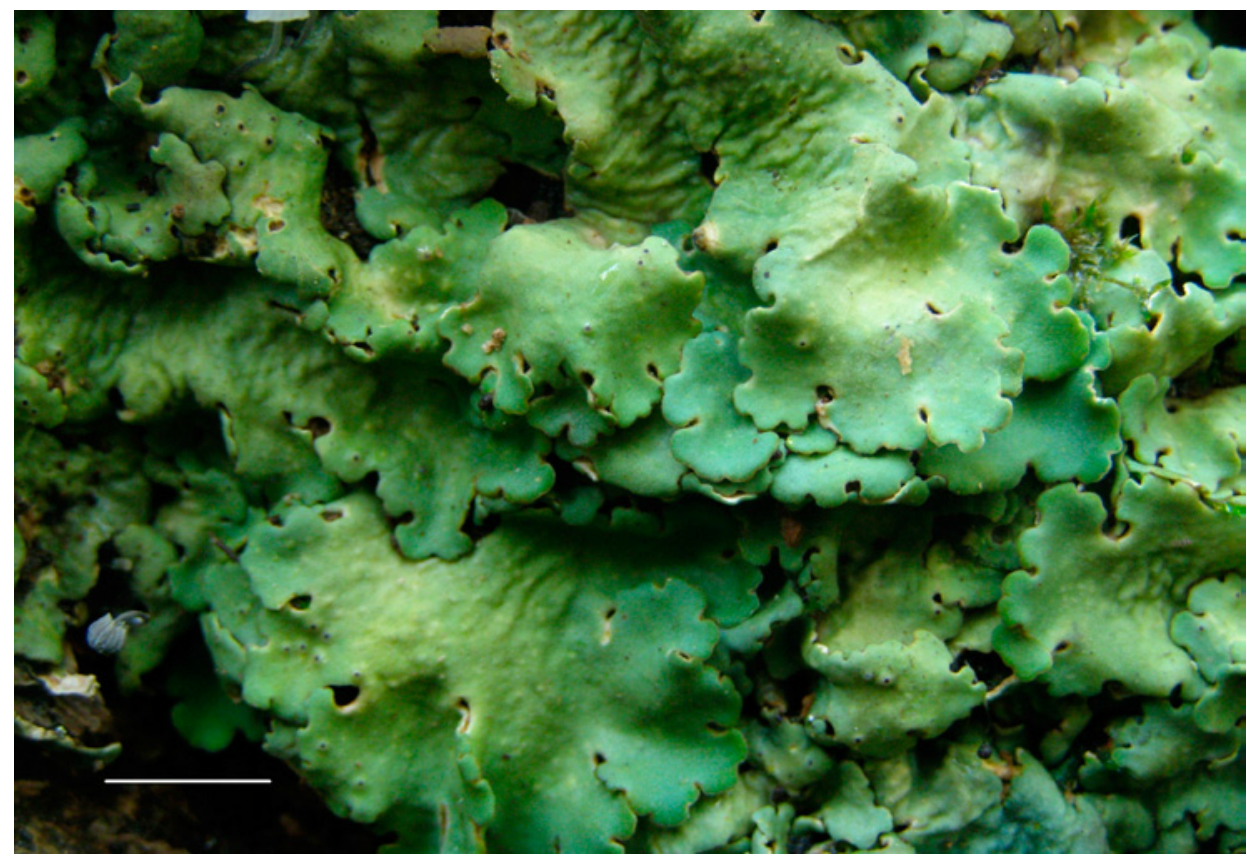

Fig. 1. Habit of Lobaria amplissima: a wet thallus with characteristic wrinkles and pycnidia. Scale bar $=1 \mathrm{~cm}$.

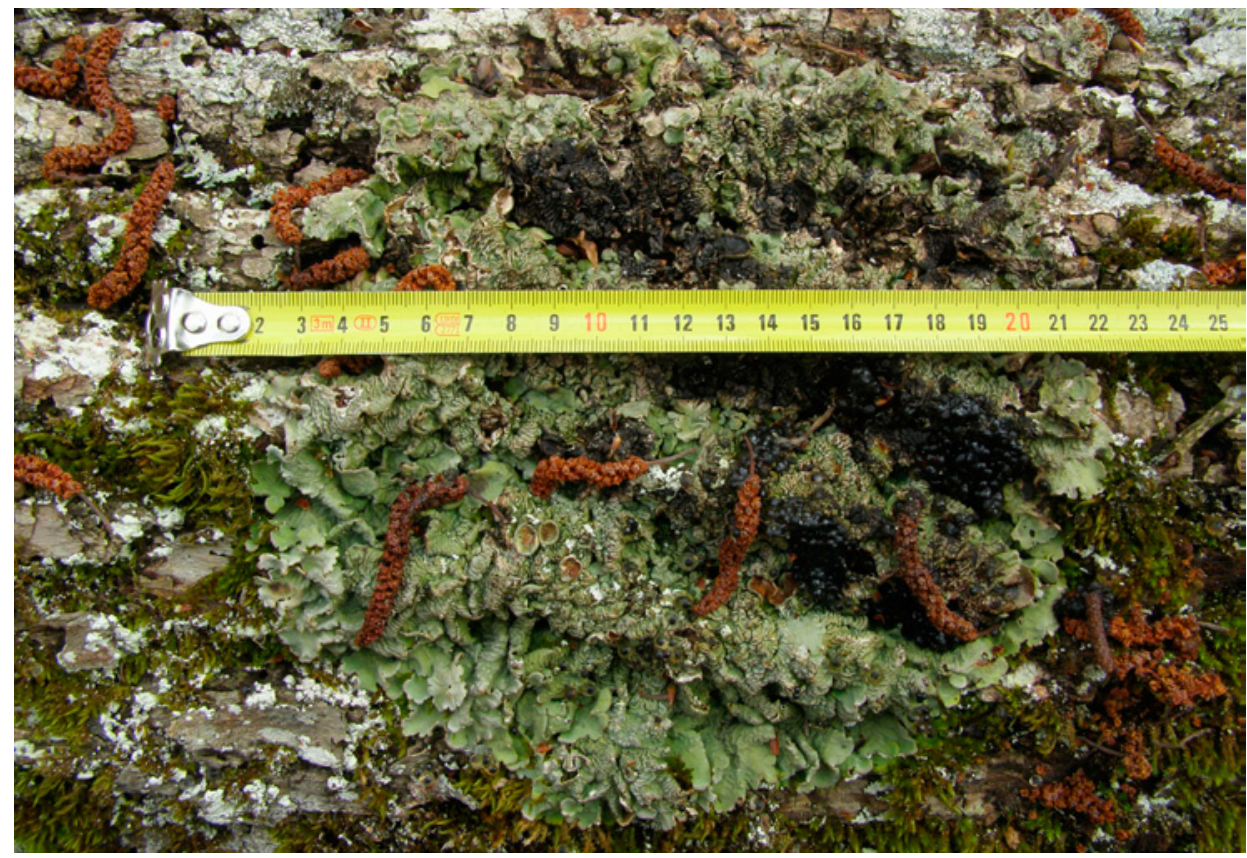

Fig. 2. Habit of Lobaria amplissima: a large rosette with a partly damaged thallus and apothecia. 



\section{RESULTS}

Lobaria amplissima (Scop.) Forssell Bih. Kong. Svenska Vetensk.- Akad. Handl. 8 (3): 111 (1883); ELichen amplissimus Scop., Fl. Carniol. Ed. 2, 2: $386(1772)$.

Morphology and anatomy. Thallus foliose, leathery, thick (up to 490-645 $\mu \mathrm{m}$ acc. to Tønsberg and Jørgensen 2007), often exceeding $30 \mathrm{~cm}$ in diam., forming rosettes or irregularly branched, wavy, discrete at apices, contiguous and overlapping towards centre. The size of the Polish material is usually smaller than that given in the literature (Rose and Purvis 2009). Thalli were mostly irregular, rarely rosette-forming 1-5(10-30) cm in diam. Lobes 5-10(15-20) $\mathrm{mm}$ wide, with rounded or truncated apices, minutely indented or sinuate-indented; some margins slightly downturned. Upper surface matt, grey-white or silvery-white when dry (yellow-brown in old herbarium materials), greenish-grey when wet, smooth or slightly to very strongly wrinkled, especially in the centre of thallus; margins of young lobes having fine crystalline frosting when dry. Lower surface pale brown, paler towards margin and dull brown in the centre; tomentose without naked spots; "hairs" whitish or brownish 0.15-0.2 $\mathrm{mm}$ long; margins of downturned lobes with white rim 0.5-1.0 mm wide without tomentum, sinuate margins sometimes with tomentum up to the edge ("hairs" are visible from the upper side of the thallus); in the centre of thallus scattered groups of rhizines, up to 2(4) mm long, 0.10-0.15 mm diam., rhizines fasciculate, partly glued at base, ends untangled, the base of thicker rhizines with whitish, short perpendicular outgrows, bottle brush-like. Photobiont in thallus chlorococcoid 7-14 $\mu \mathrm{m}$ diam. and cyanobacteria (Nostoc) in frequently occurring cephalodia. Cephalodia internal and often also superficial, globose on the lower side or shrub-like, densely branched on the upper side, blue-green-brown or brownish black, up to $2 \mathrm{~cm}$ in diam. Secondary foliose thalli sometimes attached to branches of cephalodia (Tønsberg, Jørgensen 2007). Fruticose cephalodia sometimes occurring independently as a blue-green morphotype (Stenroos et al. 2003) earlier known as Dendriscocaulon umhausense (Auersw.) Degel. External cephalodia occasionally absent, as in the material from Poland (Figs 1,2). Soralia and isidia absent. Apothecia occasional, usually not present on the thallus of specimens with fruticose cephalodia (Tønsberg, Jørgensen 2007), lecanorine, (0.2)0.5-0.7 mm diam., constricted at base, disc red-brown, shiny, concave; margin rather thick, entire or slightly crenulated; very young apothecia sometimes "erumpent" from the layers lying beneath, with cracked rim of upper cortex tissues. Ascospores 36-65 x 3.5-6(7) $\mu \mathrm{m}, 1-3$ septate, fusiform - straight or slightly sigmoid, colourless at first, becoming pale yellowish-brown. Apothecia in the Polish specimens very rare, young or older and partly damaged. Pycnidia frequent, scattered, ca. $150 \mu \mathrm{m}$ diam., immersed in conical or rather crater-like warts $0.7-1.2 \mathrm{~mm}$ diam., ostiolum black, concave; ostiolum often opened in the form of an elongated crack, not as a rounded hole; upper part of pycnidium wall two-layered as described by Tønsberg and Jørgensen (2007): inner part of greyish tissues K+ aeruginose and outer part brownish, K-. Conidia simple, bacilliform 4-5 x 1-1.5 $\mu \mathrm{m}$.

Chemistry. According to Ellix and Tønsberg (2006), the species produces depsides: m-scrobiculin (major), p-scrobiculin (submajor), an orselinate derivative 
- pseudocyphellarin A (minor) and an unknown scrobiculin derivative (trace). Tønsberg and Jørgensen (2007) additionally noted atranorin. Both form of scrobiculin were detected by TLC in all of Polish examined specimens (A. Zalewska 2011). Atranorin was observed only in thalli from two localities (see below). Other additional substances did not occur. Spot test reactions: upper cortex: $\mathrm{K}+$ bright yellow, PD-, C-, KC-; medulla: K+ dull yellow, PD-, C-, KC+ deep pink or reddish pink (reaction clearly visible through the cortex, only from the lower side of the thallus). Ecology. The occurrence of Lobaria amplissima in Poland is confined to well-preserved forest communities. The species was recorded mostly in wet alder forests, rarely in wet mixed forests. It was found exclusively on the bark of fallen Fraxinus excelsior, recently broken and gradually dying. Thalli were observed on the trunk near the tree crown and on the thick branches.

Accompanying taxa included species such as Acrocordia gemmata, Calicium adspersum, C. salicinum, Chrysothrix candelaris, Evernia prunastri, Lecanora expallens, Lepraria incana, L. vouauxii, Lobaria pulmonaria, Ochrolechia turneri, Pertusaria amara and Ramalina farinacea.

According to literature sources, Lobaria amplissima prefers the bark of old deciduous trees in woodland tree stands. It was observed on the bark of Fraxinus, Ulmus, Acer pseudoplatanus and Quercus (Rose, Purvis 2009). The species is also known from the bark of Alnus (Suza 1933), Castanea, Fagus (Nimis 1993) and Larix (see the data on the exsiccates analysed). L. amplissima was rarely recorded on mossy acidic rocks (e.g., Tønsberg, Jørgensen 2007). Aptroot and Zielman (2004) described interesting records of the species growing on bare lava rocks.

Lobaria amplissima is a member of Lobarion communities (Barkman 1958). Its occurrence in woodlands is confined to the best preserved forest communities with the structure, microclimate and ecological processes of the highest natural quality. It has indicator properties and is used to identify forests of special value for protection purposes (Rose 1992; Arup 1997; Nitaré 2000; Coppins, Coppins 2002; Czyżewska, Cieśliński 2003).

World distribution. Lobaria amplissima occurs mostly in Europe, where it has an oceanic-suboceanic distribution range. It has been reported from the lowlands and uplands in the western countries and almost exclusively from mountains in the Mediterranean region and Central Europe (Suza 1933; Degelius 1935; Lisická 2005; Wirth 2008). This species is known e.g., from Spain (Burgaz, Fuertes 1992), Italy (Nimis 1993), Germany (Wirth 1995), Portugal (van den Boom, Giralt 1996), Slovakia (Pišút et al. 1996), Latvia (Anonymus 1996), Ukraine (Kondratyuk et al. 1998; Kukwa 2002), the Czech Republic (Vězda, Liška 1999), Slovenia (Suppan et al. 2000), Austria (Hafellner, Türk 2001), Romania (Kondratyuk et al. 2003), Switzerland (Clerc 2004), Denmark, Finland, Norway and Sweden (Santesson et al. 2004), Poland (Kukwa et al. 2008), Croatia (Partl 2009), Great Britain and Ireland (Rose, Purvis 2009).

Outside Europe, L. amplissima occurs in Macaronesia (Haffelner 1995), Asia, New Zealand (Degelius 1935), North America (Tønsberg, Goward 2001) and in northern Africa (Egea 1996; Seaward 1996).

Remarks. Lobaria amplissima is a stenotopic lichen species and its survival in woodlands depends on the continuity of specific ecological factors conditioned by old-growth forests, especially the presence of old (mossy) trunks, high air humidity 
and, to some extent, the access of light (Nimis 1993; Rose, Purvis 2009). As the number of its localities has been decreasing mostly due to air pollution and forest management, L. amplissima is considered to be vulnerable in many European countries except Great Britain and Norway. It is mostly classified as critically endangered or endangered e.g., in Germany (Wirth et al. 1996), Austria (Türk, Haffelner 1999), Switzerland (Scheiddeger et al. 2002) and the Czech Republic (Liška et al. 2008).

Many localities previously known from European lowlands may be vanishing, as in Latvia (Anonymus 1996) and Denmark (Søchting, Alstrup 2002), where L. amplissima was classified as an extinct species. It seems that the Białowieża Forest in Poland is the last refuge of this species in the lowlands of Central Europe.

The species has not been red-listed in Poland (Cieśliński et al. 2006) due to the former taxonomic classification of the specimen known as L. virens (see introduction). However, as habitats characteristic of L. amplissima are becoming extinct and the number of its localities is small, the taxon seems to fully deserve to be included in the next edition of the red list. Cieśliński (2010) proposed the CR category for $L$. amplissima, as previously for L. virens.

Distribution in Poland. L. amplissima has been recorded at nine localities in Poland. It occurs exclusively in the Białowieża Forest (Kukwa et al. 2008, present work).

Locality known prior to this paper. ATPOL grid square Cg 54 - Równina Bielska plain, Białowieża Forest, Białowieża forest division, Zwierzyniec forest district, "Natural Woodlands of Białowieża Forest" reserve (=NWBF reserve), forest section 392B, wet deciduous forest near the Krynica river, on fallen Quercus robur, s.dat. (cf. 1981-1984), leg. S. Cieśliński \& Z. Tobolewski (BSG) (Kukwa et al. 2008, Cieśliński pers. comm. 2010).

Specimens eXAmined [all on bark of fallen Fraxinus excelsior]. Cg 54 - Równina Bielska plain, Białowieża Forest, Białowieża forest division, Zwierzyniec forest district, NWBF reserve, forest section No. 392D, 52 $42^{\prime} \mathrm{N}, 23^{\circ} 43^{\prime} \mathrm{E}$, wet alder forest, $10 \mathrm{Febr}$. 2011, leg. A. Bohdan (specimen with additional substance - atranorin). Cg 55 - Równina Bielska plain, Białowieża Forest, Białowieża National Park, forest section No. 256C, $52^{\circ} 46^{\prime} \mathrm{N}, 23^{\circ} 52^{\prime} \mathrm{E}$, wet alder forest, 12 May 2011, leg. A. Bohdan. Cg 64 - Równina Bielska plain, Białowieża Forest, Hajnówka forest division, Sacharewo forest district, NWBF reserve, forest section No. 464B, $52^{\circ} 41^{\prime} \mathrm{N}, 2^{\circ} 39^{\prime} \mathrm{E}$, wet alder forest, 28 April 2010, leg. A. Bohdan; ibid., forest section No. 464D, 52 $41^{\prime} \mathrm{N}, 23^{\circ} 39^{\prime} \mathrm{E}$, wet alder forest, 28 April 2010, leg. A. Bohdan (specimen with additional substance - atranorin). Cg 65 - Równina Bielska plain, Białowieża Forest, Białowieża forest division, Grudki forest district, NWBF reserve, forest section No. $548 \mathrm{C}, 52^{\circ} 39^{\prime} \mathrm{N}, 23^{\circ} 47^{\prime} \mathrm{E}$, and $52^{\circ} 39^{\prime} \mathrm{N}, 23^{\circ} 46^{\prime} \mathrm{E}$, both in wet alder forest, 3 Oct. 2010, leg. A. Bohdan; ibid., 52 $2^{\circ} 39^{\prime} \mathrm{N}, 23^{\circ} 46^{\prime} \mathrm{E}$; wet mixed forest, 3 Oct. 2010, leg. A. Bohdan; ibid., forest section No. 609B, $52^{\circ} 38^{\prime} \mathrm{N}, 23^{\circ} 47^{\prime} \mathrm{E}$, wet mixed forest, 23 Sept. 2010, leg. A. Bohdan.

ExsicCATAE SEen. Lobaria amplissima: Pišút, Lich. Slov. Exs. No. 108, Slovakia centr., Nízkie Tatry ad corticem Fagi silvaticae in valle Bystrá dolina, alt. 1220 m, 3.08.1966, leg. I. Pišút (KRAM-L-25948) $\mathrm{m}$-scrobiculin and p-scrobiculin, atranorin detected by TLC (A. Zalewska, 2.04.2012); Poelt, Lich. Alpium No. 142, Ammergrauer Alpen, Schwaben: Bleckenau über Hohenschwangau, auf Fagus im Bergwald, bei alt. $1350 \mathrm{~m}$, leg. H. Doppelbaur et A. Schröppel, cum ap., with abundant shrubby cephalodia on upper side (KRAM-L-23694) - m-scrobiculin and p-scrobiculin detected by TLC (A. Zalewska, 2.04.2012); Suza, Lich. Bohem. No. 70, Rossia Subcarpatica, Carpati Poloniny region montes Svidovec, in convalle rivi Kosovská rika, supra cortices Fagorum alt. ca 700-800 m, cum ap., with some shrubby cephalodia on upper side (KRAM-L-25610) - m-scrobiculin and p-scrobiculin detected by TLC (A. Zalewska, 2.04.2012); Suza, Lich. Bohem. No. 284, Rossia Subcarpatica (ČSR): Brecedel supra pag. Trebušany ad stirpes Fagorum alt. ca $1000 \mathrm{~m}$, cum ap., s.c. (KRAM-L-25775) - m-scrobiculin and p-scrobiculin, atranorin detected by TLC (A. Zalewska, 2.04.2012); Versheghy, Lich. Exs. No. 71, Italia, Siena, Badia S. Salvatore, in m. Amiata, in rup. et ad cort., alt. ca. $1000 \mathrm{~m}, 10.1937$, leg. C. Sbarbaro, cum ap. (KRAM-L-23886) - mscrobiculin and p-scrobiculin, atranorin detected by TLC (A. Zalewska, 2.04.2012); Lobarina scrobiculata: Arnold, Lich. Exs. No. 1466, München, Grünwalder Park südwestlich von Wörbrunn; an der obersten 
Aesten alter Eichen, 6.10.1889, s.c. (KRAM-L-8124) - m-scrobiculin and p-scrobiculin, norstictic, stictic and constictic acids detected by TLC (A. Zalewska, 2.04.2012).; Savich, Lich. Ross. No. 140, Rossia septentronalis peninsula Kolaensis, ad rupes gneissaceas apud ostium fl. Kolmak in fl. Ponoj., 1928, leg. J. D. Zinserling, det. 1963 V. P. Savich (KRAM-25591) - m-scrobiculin and p-scrobiculin, norstictic, stictic and constictic acids detected by TLC (A. Zalewska, 2.04.2012); Poelt, Lich. Alpium No. 188, Ötztaler Alpen, Nordtirol: am Larix - Stämmen im Sprühregen des Stuibenfalles bei Uhausen im Ötztal, 1200 m, 1959, leg. M. Steiner (KRAM-L-23735) - m-scrobiculin and p-scrobiculin, norstictic, stictic and constictic acids detected by TLC (A. Zalewska, 2.04.2012); Suza, Reliq. Suza. No. 33, Czechoslovakia ČSSR (Bohemoslovakia), Moravia occid., Velké Meziřiči, prope pagum Baliny, in rupibus graniticis muscosis, 06.1929, leg. J. Suza (KRAM-L-18822) - usnic acid, m-scrobiculin and p-scrobiculin, norstictic, stictic and constictic acids detected by TLC (A. Zalewska, 2.04.2012); Lobaria quercizans Michx.: as Lobaria amplissima -Arnold, Lich. Exs. No. 1217, Insel Miquelon in Nordamerika (= New Funland, Canada), 1886, leg. Delamare (KRAM-L-647) - gyrophoric acid detected by TLC (A. Zalewska, 2.04.2012); as Lobaria amplissima (Ricasolia amplissima) ex Herb. Musei Palat. Vindob., Ins. Miquelon (= New Funland, Canada), leg. Delamare (KRAM-L-34153) - gyrophoric acid detected by TLC (A. Zalewska, 2.04.2012).

Additional SPECIMENS SEen. Lobaria amplissima - Ukraine, Eastern Carpathians, Czywczyn Mts, Kamieniec Prełuczny Mt., alt. 1310 m, on Fagus sylvatica, 11.08.1934, leg. T. Sulma (KRAM-L-48214, ex UGDA-L-5367) - m-scrobiculin and p-scrobiculin detected by TLC (A. Zalewska, 2011); Bulgaria, s.l. 10.1960, s.c. (KRAM-L-5162) - m-scrobiculin and p-scrobiculin detected by TLC (A. Zalewska, 2011). Lobarina scrobiculata - Poland, Tatry Mts, s.1., 1889, s.c. (KRAM-L-10717) - usnic acid, m-scrobiculin and p-scrobiculin, norstictic, stictic and constictic acids detected by TLC (A. Zalewska, 2012); Bieszczady Mts, Ustrzyki Górne, alt. $680 \mathrm{~m}$, boggy alder forest by river Rzeszyca, on the bark of Alnus, 27.08.1957, leg. K. Glanc (KRAM-L-35776) - m-scrobiculin and p-scrobiculin, norstictic, stictic and constictic acids detected by TLC (A. Zalewska, 2012). Lobaria virens - s.l., s.c. (KRAM-L-18470) - no substances detected by TLC (A. Zalewska, 2011).

\section{DISCUSSION}

Lobaria amplissima is a fairly characteristic species although some forms can be confused with other members of the genus Lobaria, especially when the thallus is wet (and greenish in colour) and black-brown fruticose cephalodia are lacking. The species is distinguished by a matt, grey-whitish upper side of the thallus (when dry), sinuate-indented small lobes, the upper cortex reacting with $\mathrm{K}+$ bright yellow and medulla spot colour reaction tests $\mathrm{P}-, \mathrm{KC}+$ deep pink or reddish pink. It produces $\mathrm{m}$-scrobiculin and $\mathrm{p}$-scrobiculin and sometimes pseudocyphellarin and/or atranorin as the accessory substances.

Among the species which can grow in similar habitats, Lobaria virens bears the greatest resemblance to L. amplissima. The former differs from Lobaria amplissima by having a thinner thallus (up to $300 \mu \mathrm{m}$ acc. to Tønsberg and Jørgensen 2007) with a green to pale greyish-brown upper side when dry, often shiny, smooth or rarely wrinkled (the thallus is green when moist, as in L. amplissima). Apothecia of $L$. virens are always present and are bigger (to $11 \mathrm{~mm}$ in diam.) with a brown (Tønsberg, Jørgensen 2007) or rose- to orange-red disc (Wirth 1995). Its ascospores are shorter and wider, 32-47 x 6-8(10) $\mu \mathrm{m}$. The morphology of pycnidia and the size of conidia are similar in both species but the shape of conidial cells is different. Conidia of $L$. virens are widening at the ends in contrast to bacilliform conidia of $L$. amplissima. $L$. virens has only internal cephalodia with cyanobacteria. The photobiont in the thallus is a green algae. This species does not produce secondary substances. $L$. virens is a 
very rare lichen, endangered in Central Europe. It does not occur in Poland but it may be possible to find its sites in well-preserved forests.

Lobarina scrobiculata and Lobaria pulmonaria are distinguished from Lobaria amplissima by the thallus with depressions and ridges, broader lobes up to $4.5-5 \mathrm{~cm}$, and by vegetative, symbiotic propagules (isidioid consoredia and typical isidia and soredia, respectively) lacking in L amplissima.

Lobarina scrobiculata also varies in having only one type of photobiont: cyanobacteria (Nostoc). Due to the presence of cyanobacteria the wet thallus of this species is dark grey-blue (yellowish-grey to blue-grey with a brownish margin when dry). The thallus of Lobaria pulmonaria contains other green algae: Dictyochloropisis reticulata with big cells (up $20 \mu \mathrm{m}$ in diam.) and cyanobacteria inside the internal cephalodia. Its thallus is vivid green when wet and yellowish grey or brown when dry.

The two species have also different chemical properties. Similarly to Lobaria amplissima, also Lobarina scrobiculata contains m-scrobiculin as a major compound, p-scrobiculin as a submajor substance and additionally usnic acid (minor) and the stictic acid complex, including norstictic acid (I chemotype) or usnic acid without the stictic complex (II chemotype). Its medulla reacts $\mathrm{C}-$ and $\mathrm{KC}+$ deep orange-pink as in L. amplissima, but unlikely to this species, $\mathrm{P}+$ orange and $\mathrm{K}+$ yellow (acc. to Rose and Purvis (2009). Tønsberg and Jørgensen (2007) give other data on colours for Lobarina scrobiculata - I chemotype: $\mathrm{C}-, \mathrm{KC}-, \mathrm{P}+$ orange, $\mathrm{K}+$ yellow to orange, II chemotype: $\mathrm{C}-, \mathrm{KC}-, \mathrm{P}-, \mathrm{K}-$. Lobaria pulmonaria produces stictic acid as a major substance and constictic acid (submajor or minor), as well as other acids of the stictic complex in minor quantities and salazinic acid (minor). The spot colour reaction test for the medulla according to Rose and Purvis (2009) is: $\mathrm{C}-, \mathrm{KC}+$ yellow-orange, $\mathrm{P}+$ orange, K+ yellow-orange, and according to Tønsberg and Jørgensen (2007): C-, $\mathrm{KC}-, \mathrm{P}+$ orange, $\mathrm{K}+$ yellow to orange.

Flavoparmelia caperata (L.) Hale can also be similar to Lobaria amplissima. Both species have foliose, rosette-forming wrinkled thalli with a greenish tinge when moist, but when dry, F. caperata has a brighter yellow-green thallus, and moreover it produces soralia, lacks cephalodia and the tomentum on the lower side which is much darker (blackish). Its medulla reacts $\mathrm{C}-, \mathrm{KC}+\mathrm{red}, \mathrm{P}+$ orange-red, and contains protocetraric, caperatic and usnic acids (Wirth 1995). This species grows mainly in deciduous, especially oak-hornbeam forests. It prefers open stands, forest margins and free-standing trees of oak, ash, hornbeam and linden (Wirth 1995). Lobaria amplissima and Flavoparmelia caperata can grow together at more open sites in regions with high precipitation and high air humidity (e.g., oceanic sites in West Europe and in mountains). Indeed, the two lichens were observed at the same localities inside natural wet alder forests in the Białowieża Forest. Lobaria amplissima was recorded there exclusively on the bark of Fraxinus excelsior, while Flavoparmelia caperata also occurred on the trunks of Alnus glutinosa (Cieśliński 2003).

Lobaria quercizans Michx., known mostly from North America, is externally very similar to L. amplissima. Hale (1957) stressed their resemblance and different distribution. L. quercizans has not been recorded in Europe but L. amplissima has only recently been discovered in Alaska and Carolina (Tønsberg and Goward 2001). It is difficult to assess whether L. quercizans is likely to be found in Europe. It favours old-growth forests with a mixed vertical structure. This species has been observed mainly on the trunks of old Betula alleghaniensis, Thuja occidentalis and 
Acer saccharum, rarely on Fraxinus spp. and on rocks, both with and without moss (Wetmore 2002). Its thallus is brown to grey in colour, smooth, without reticulate ridges. It lacks cephalodia, soredia and isidia, and contains green algae. Brown apothecia are common (Lobaria quercizans. 2011. Minnesota Department of Natural Resources). The medulla is pink when tested with $\mathrm{C}$ due to the presence of gyrophoric acid (Wetmore 1981).

Based on the current knowledge on the identification of L. amplissima as well as characteristic habitats preferred by this lichen, rather few further localities of the species are likely to be discovered in Poland, and this only in the least human-affected forest communities. Detailed observations of old tree stands within large forest complexes in NE Poland and probably in the Bieszczady Mts should be conducted. It may be possible to find Lobaria amplissima on trunks (especially at the base of the crown) of living, standing or fallen old ashes, oaks or beeches and sycamores in the mountain forests.

\section{CONCLUSIONS}

The discussed lichen species is under the strict legal protection in Poland as a member of the genus Lobaria (acc. to the Regulation of the Minister of Environment of 2004). It should be also included into the group of lichens, that need the special zone protection. This form of the habitat protection could prevent the influence of logging, if a new localities in the managed forest will be discovered. L. amplissima should also replaced $L$. virens in the red-list of endangered lichens in Poland (with CR category) and in the list of lichen-indictors of old-growth forests in the Polish lowlands.

Acknowledgements. The authors are indebted to S. Cieśliński (Kielce) for the detailed data on the locality he supplied. We would like to express our sincere thanks to M. Fabiszewski (Lomża) for the help with GIS maps. The anonymous reviewer is warmly thanked for valuable comments on the manuscript.

\section{REFERENCES}

Anonymus. 1996. Fungi and Lichens. Red Data Book of Latvia. Vol. 1, Riga. (Latvijas Universitas) http:// latvijas.daba.lv/saraksti/keerpji/ProtLich/Protected_lichens_Latvia.html [date of exploration - 5 December 2011]

Aptroot A., Zielman R. 2004. Lobaria amplissima and other rare lichens and bryophytes on lava rock outcrops in the Eifel (Rheinland-Pfalz, Germany). Herzogia 17: 87-93.

Arup U. 1997. Skoglig kontinuitet. (In:) U. Arup, S. Ekman, I. Kärnefelt, J.-E. Mattsson (eds). Skyddsvärda lavar i sydvästra Sverige, p. 92 -95. SBF-förlaget, Lund.

Barkman J. J. 1958. Phytosociology and ecology of cryptogamic epiphytes. Van Gorcum \& Comp., Assen. 628 pp. [Reissued 1969].

Boom van den P. P. G., Giralt M. 1996. Contribution to the flora of Portugal, lichens and lichenicolous fungi I. Nova Hedwigia 63(1-2): 145-172.

Burgaz A. R., Fuertes E. 1992. Aportaciones a la vegetación epífita (Briófitos y líquenes) II. (La Rioja, Espana). Cryptogamie, Bryol. Lichénol. 13: 133-153.

Cieśliński S. 2003. Atlas rozmieszczenia porostów (Lichenes) w Polsce Północno-Wschodniej. Phytocoenosis 15 (N.S.). Suppl. Cartogr. Geobot. 15: 1-426. 
Cieśliński S. 2010. Wykaz gatunków porostów (grzybów zlichenizowanych) Puszczy Białowieskiej (NE Polska). Parki nar. Rez. Przyr. 29(2): 3-39.

Cieśliński S., Fałtynowicz W. 1993. Note from editors. (In:) S. Cieśliński, W. Fałtynowicz (eds). Atlas of the geographical distribution of lichens in Poland. 1, p. 7-8. W. Szafer Institute of Botany, Polish Academy of Sciences, Kraków.

Cieśliński S., Tobolewski Z. 1988. Porosty (Lichenes) Puszczy Białowieskiej i jej zachodniego przedpola. 1. (N. S.) Suppl. Cartogr. Geobot. 1: 1-216.

Cieśliński S., Czyżewska K., Fabiszewski J. 2006. Red list of the lichens in Poland. (In:) Z. Mirek, K. Zarzycki, W. Wojewoda, Z. Szeląg (eds). Red list of plants and fungi in Poland, p. 71-89. W. Szafer Institute of Botany, Polish Academy of Sciences, Kraków.

Clerc P. 2004. Les champignons lichénisés de Suisse. Cryptogamica Helvetica 19: 1-320.

Coppins A. M., Coppins B. J. 2002. Indices of ecological continuity for woodland epiphytic lichen habitats in the British Isles. British Lichen Society, London, 36 pp.

Czyżewska K., Cieśliński S. 2003. Lichens - indicators of lowland old-growth forests in Poland. Monogr. Bot. 91: 223-239

Degelius G. 1935. Das ozeanische Element der Strauch - und Laubflechtenflora von Skandinavien. Acta Phytogeogr. Suec. 7: 1-411.

Diederich P., Ertz D., Stapper N., Sérusiaux E., Broeck van den D., Boom van den P., Ries C. 2009. The lichens and lichenicolous fungi of Belgium, Luxembourg and northern France. http://www.lichenology.info [date of exploration - 2 Oct. 2009].

Egea J. M. 1996. Catalogue of lichenized and lichenicolous fungi of Morocco. Bocconea 6: 19-114.

Elix J. A., Tønsberg T. 2006. Notes on the chemistry of Scandinavian Lobaria species. Graphis Scripta 18: 27-28.

Fałtynowicz W. 2003. The lichens, lichenicolous and allied fungi of Poland. An annotated checklist. (In:) Z. Mirek (ed.), Biodiversity of Poland 6: 1-435. W. Szafer Institute of Botany, Polish Academy of Sciences, Kraków.

Hafellner J. 1995. A new checklist of lichens and lichenicolous fungi of insular Laurimacaronesia including a lichenological bibliography for the area. Fritschiana 5: 1-132

Hafellner J., Türk R. 2001. Die lichenisierten Pilze Österreichs-eine Checkliste der bisher nachgewiesenen Arten mit Verbreitungsangaben. Stapfia 76: 1-167.

Hale M. 1957. The Lobaria amplissima - L. quercizans complex in Europe and North America. Bryologist 60 (1): 35-39.

Kondratyuk S. Ya., Khodosovtsev A. Ye., Zelenko S. D. 1998. The second checklist of lichen forming, lichenicolous and allied fungi of Ukraine. Phytosociocentre, Kiev, $180 \mathrm{pp}$.

Kondratyuk S. Ya., Popova L. P., Lackovičová A., Pišút I. 2003. A catalogue of Eastern Carpathian lichens. M. H. Kholodny Institute of Botany, National Academy of Sciences of Ukraine; Institue of Botany, Slovak Academy of Sciences, Kiev - Bratislava, 246 pp.

Kukwa M. 2002. Contribution to the flora of lichenized Ascomycotina of the Czywczyn Mts. (Eastern Carpathians, Ukraine). IV. Lobaria, allied genera and their lichenicolous fungi. Herzogia 15: 51-55.

Kukwa M., Schiefelbein U., Czarnota P., Halda J., Kubiak D., Palice Z., Naczk A. 2008. Notes on some noteworthy lichens and allied fungi found in the Białowieża Primeval Forest in Poland. Bryonora 41: 1-11.

Lisická E. 2005. The lichens of the Tatry Mountains. VEDA, Bratislava, 439 pp.

Liška J., Palice Z., Slavíková Š. 2008. Checklist and Red List of lichens of the Czech Republic. Preslia 80: 151-182.

Lobaria quercizans. 2011. Minnesota Department of Natural Resources http://www.dnr.state.mn.us/rsg/ profile.html action = elementDetail\&selectedElement=NLLEC0G090\# [ date of exploration -9 December 2011]

Nimis P. J. 1993. The lichens of Italy. An annotated catalogue. Monographie XII, Museo Regionale di Scienze Naturali, Torrino, 899 pp.

Nitarè J. (ed.). 2000 Signalarter. Indikatorer pa skyddsvärd skog. Flora över kryptogamer. Skogsstyrelsens förlag, Jönköping, 384 pp.

Nowak J., Tobolewski Z. 1975. Porosty polskie. Opisy i klucze do oznaczania porostów w Polsce dotychczas stwierdzonych lub prawdopodobnych. Wydawnictwo Naukowe PWN, Warszawa - Kraków, 1077 pp.

Orange, A., James, P. W., White, F. J. 2001. Microchemical methods for the identification of lichens. British Lichen Society, London, 101 pp. 
Partl A. 2009. Checklist of lichens and lichenicolous fungi of Croatia. University of Osijek, Croatia, Preliminary version 1 March 2009. http://www.biologie.uni-hamburg.de/checklists/lichens/europe/ croatia_l.htm [date of exploration - 9 December 2011].

Pišút I., Lackovicová A., Lisická E. 1996. A second checklist and bibliography of Slovak lichens. Biologia (Bratislava) 51 (3): 1-79.

Regulation of the Minister of Environment of 2004. Rozporządzenie Ministra Środowiska z dnia 9 lipca 2004 r. w sprawie gatunków dziko występujących grzybów objętych ochroną (Dz. U. Nr 168, poz. 1765).

Rose F. 1992. Temperate forest management: its effect on bryophyte and lichen habitats. (In:) W. Bates, A. M. Farmer (eds). Bryophytes and lichens in a changing environment, p. 211-233. Clarendon Press, Oxford.

Rose F., Purvis, O. W. 2009. Lobaria (Schreber) Hoffm. (1796). (In:) C.W. Smith, A. Aptroot, B. J. Coppins, A. Fletcher, O.L. Gilbert, P. W. James, P. A. Wolseley (eds). The Lichens of Great Britain and Ireland, p. 560-562. The Britsh Lichen Society, The Natural History Museum, London.

Ryś A. 2005. Granicznik płucnik Lobaria pulmonaria w lasach państwowych i jego ochrona. Studio Avalon, Krutyń, 28 pp.

Santesson, R., Moberg, R., Nordin, A., Tønsberg, T., Vitikainen, O. 2004. Lichen-forming and lichenicolous fungi of Fennoscandia. Uppsala, Museum of Evolution, Uppsala University, Uppsala, 359 pp.

Scheidegger C., Clerc P., Dietrich M., Frei M., Groner U., Keller C., Roth I., Stofer S., Vust M. 2002. Rote Liste der gefährdeten Arten der Schweiz: Baum- und erdbewohnende Flechten. Bern, Bundesamt für Umwelt, Wald und Landschaft BUWAL; Birmensdorf, Eidgenössische Forschungsanstalt WSL, $124 \mathrm{pp}$.

Seaward M. R. D. 1996. Checklist of Tunisian lichens. Bocconea 6: 115-148.

Smith C.W., Aptroot A, B. J. Coppins, A. Fletcher, O.L. Gilbert, P. W. James, P. A. Wolseley (eds). 2009. The Lichens of Great Britain and Ireland. The Britsh Lichen Society, The Natural History Museum, London, $1046 \mathrm{pp}$.

Søchting U, Alstrup, V., 2002. Danish Lichen Checklist. Ver. 2. Botanical Institute, University of Copenhagen, Copenhagen. www.bi.ku.dk/lichens/dkchecklist/ [date of exploration: 9 December 2011].

Stenroos S., Stocker-Wörgötter E., Yoshimura I., Myllys L., Thell A., Hyvönen J. 2003. Culture experiments and DNA sequence data confirm the identity of Lobaria photomorphs. Can. J. Bot. 81(3): 232-247.

Suppan U., Prügger j., Mayrhofer H. 2000: Catalogue of the lichenized and lichenicolous fungi of Slovenia. Bibl. Lichenol. 76: 1-215.

Suza J. 1933. Ozeanische Züge in der epiphytischen Flechtenflora der Ostkarpathen (ČSR.), bzw. Mitteleuropas. Vestnik Krịlovské Ceské Společnosti Nauk 2: 1-43.

Tønsberg T., Goward T. 2001. Sticta oroborealis sp. nov. and other Pacific North American lichens forming dendriscocauloid cyanotypes. Bryologist 104: 12-23.

Tønsberg T., Jørgensen P. M. 2007. Lobaria. Nordic Lichen Flora 3: 77-82.

Türk R., Haffelner J. H. 1999. Rote Liste gefährdeter Flechten (Lichenes) Österreichs. 2. Fassung. (In:) H. Niklfeld (ed.). Rote Listen gefährdeter Pflanzen Österreichs. 2 Auflage. Grüne Reihe des Bundesministeriums für Umwelt, Jugend und Familie, 10, p. 187 -228. Graz.

Vězda A., Liška J. 1999. Katalog Lišejníků České Republiky. Institute of Botany, Academy of Sciences of the Czech Republic, Průhonice, 283 pp.

Wetmore C. M. 1981. Keys to the Lichens of Minnesota. Department of Plant Biology, University of Minnesota, St. Paul, Minnesota, 92 pp. [Revised 2005].

Wetmore C. M. 2002. Conservation assessment for Lobaria quercizans Michx. United States Forest Service, Eastern Region, Milwaukee, Wisconsin, 18 pp.

Wirth V. 1995. Die Flechten Baden-Württembergs. Verlag Ulmer, Stuttgart, 1006 pp.

Wirth V. 2008. Rote Liste und Artenverzeichnis der Flechten Baden-Württembergs - Stand 2008. P LUBW. Landesanstalt für Umwelt, Messungen und Naturschutz Baden-Württemberg, Verlag Regionalkultur, Karlsruhe, 64 pp.

Wirth V., Schöller H., Scholz P., Ernst G., Feuerer T., Gnüchtel A., Hauck M., Jacobsen P., John V., Litterski, B. 1996. Rote Liste Der Flechten (Lichenes) der Bundesrepublik Deutschland. Schriftenreihe Vegetationsk. 28: 307-368. 
Nowe stanowiska Lobaria amplissima (Lobariaceae, Ascomycota) w Polsce

\section{Streszczenie}

Lobaria amplissima jest porostem znanym głównie z Europy, ale posiada również stanowiska w Makaronezji, Azji, Nowej Zelandii, a także w Ameryce Płn. i północnej części Afryki. Typ jej rozmieszczenia w Europie można określić jako oceaniczno-suboceaniczny, od Norwegii po Portugalię. Dalej w kierunku wschodnim występuje głównie w górach, np. w regionie śródziemnomorskim i w Europie Centralnej. Lobaria amplissima rośnie na pniach lub grubych konarach starych drzew liściastych, bezpośrednio na korze lub na epifitycznych mszakach. Rzadziej notowana jest na omszonych kwaśnych skałach. Porost ten jest bardzo wrażliwy na zanieczyszczenia powietrza i przekształcenia zbiorowisk leśnych, spowodowane zabiegami gospodarczymi. Jest on składnikiem ugrupowań epifitycznych ze związku Lobarion i jego występowanie ograniczone jest do najlepiej zachowanych ekosystemów leśnych. Pierwsze stanowisko L. amplissima w Polsce podali Kukwa i in. (2008) w wyniku rewizji okazu zdeponowanego w BSG, zebranego w Puszczy Białowieskiej i znanego wcześniej jako L. virens (Cieśliński i Tobolewski 1988; Cieśliński 2003, 2010). Kolejne stanowiska L. amplissima zostały ostatnio znalezione przez A. Bohdana, w wilgotnych lasach olszowych w obrębie kilku części rezerwatu „Lasy Naturalne Puszczy Białowieskiej” i Białowieskiego Parku Narodowego. Wszystkie notowania pochodzą z kory przewróconych starych jesionów. Plechy zlokalizowane były w podkoronowej części pni i w koronie. W Polsce L. amplissima zarejestrowana została łącznie na 9 stanowiskach w Puszczy Białowieskiej, która jest prawdopodobnie ostatnim refugium tego gatunku na Niżu Środkowo-Europejskim. Omawiany gatunek, podobnie jak inni przedstawiciele rodzaju Lobaria, jest porostem ściśle chronionym w Polsce. W niedalekiej przyszłości powinien być objęty ochroną strefową, która dodatkowo zabezpieczy potencjalne nowe stanowiska, zwłaszcza jeżeli zostaną znalezione w lasach gospodarczych. L. amplissima powinna być także wprowadzona w miejsce $L$. virens na krajową czerwoną listę gatunków zagrożonych oraz do zestawienia indykatorów lasów puszczańskich. W pracy przedstawiono jedno dotychczas znane oraz nowe stanowiska L. amplissima, stwierdzone w latach 2010 i 2011 . Uzyskane wyniki oraz przegląd danych dotyczących ekologii tego gatunku wskazują, że możliwe jest znalezienie w Polsce nielicznych nowych stanowisk tego rzadkiego porostu, ale tylko w najmniej zniekształconych lasach liściastych, o charakterze puszczańskim. Potencjalne miejsca występowania wydają się być ograniczone do dużych kompleksów leśnych w północno-wschodniej Polsce i w Bieszczadach. Najbardziej prawdopodobnymi forofitami mogą być jesiony w łęgach i olsach, jesiony i dęby w wilgotnych postaciach grądów, buki i jawory w zbiorowiskach leśnych w górach. Przeszukiwane powinny być górne części pni i grube, dolne konary przewróconych drzew. Obserwacje drzew stojących, za pomocą lornetki ornitologicznej, umożliwiają zauważenie tylko dużych (do 20-30 cm średnicy) plech, występujących dość rzadko (Ryc.2). Ze względu na podobieństwo, głównie do Lobaria virens i Flavoparmelia caperata, konieczne są badania laboratoryjne, $w$ tym TLC. Najbardziej istotne cechy diagnostyczne omawianego gatunku to jasnoszara (w stanie suchym) górna powierzchnia plechy (wilgotna - szaro-zielona), z wyraźnymi marszczeniami w części środkowej i drobne, do $2 \mathrm{~cm}$ szerokości, karbowano-wcinane, częściowo podwinięte łatki. W materiałach z Polski nie stwierdzono bardzo charakterystycznych, brązowo-czarnych krzaczkowatych cefalodiów, występujących na górnej stronie plechy. Plechy zawierają skrobikulinę, rzadziej pseudocyfellarynę i atranorynę. Górna kora barwi się od $\mathrm{KOH}$ intensywnie jasno żółto, charakterystyczne są również reakcje miąższu: $\mathrm{K}+$ ciemno żółty, PD-, C-, KC+ ciemno różowy lub czerwono-różowy. 